\title{
Occurrence of a new Genus of Troglobitic Nicoletiidae (Ins., Thysanura) in Mexico
}

\author{
By J. PACLT ${ }^{1)}$
}

With plate 127 (1)

When, in 1963, in my synopsis of Nicoletiidae, I synonymized tentatively the poorly described Nicoletia texensis Ulrich with Nicoletia (Anelpistina) wheeleri Silvestri, I was certainly not prepared to must correct myself within few years to follow. The error became evident when I received for examination two specimes of a most distinctive type of Nicoletiidae collected, in 1964, by Professor C. Kosswig, the director of the Zoological Institute of Hamburg (Germany), on his Mexico journey. Both specimens were captured on 11 April in the Quintero caves (Grutas de Quintero), Valles al Mante, Tamaulipas, and will be deposited with the Hamburg Zoological Museum.

The present investigation confirms the existence of Ulrich's type of Nicoletia in which the lengthening of legs, cerci, antennae and other appendages reaches its known maximum. Among Diplura, nearly the same degree of lengthening of the appendages may be observed in Plusiocampa dargilani (Moniez), a troglobitic Campodeidae from France.

The male of Nicoletia texensis Ulrich does not possess submedian processes on urosternite IV and the species differs thus from all members of the subgenus Anelpistina Silv., type Nicoletia wheeleri Silv. from Texas. The numbers of styli and eversible vesicles of Nicoletia texensis Ulrich, 8 and 6 pairs respectively, fit with the definition of the genus Nicoletia. On the other hand, a different structure of the median claw separates the species described by Ulrich from the Nicoletia complex, and requires the erection of a new genus for it.

Nicoletia texensis Ulrich being, however, under redescription, it seems premature to create the relevant new genus in the present article. The species has been described originally from Ezell's cave in Hays County, Texas. Further Texas records are included in the recent checklist by Reddell (1966). It, N. texensis, is one of the most remarkable cavernicolous forms

1) Slovak Academy of Sciences, Bratislava: Institut of Exptl Phytopathology and Entomology, Ivanka pri Dunaji, Czechoslovakia. 
of the family. Its presence in the Quintero caves suggests a close affinity between Texas and Mexico subterranean environments, although strongly endemic species of Crustacea ${ }^{1)}$ live either of them.

juin 1968

\section{RÉSUMÉ}

L'auteur a examiné deux spécimens de Nicoletia texensis U1rich provenant des grottes de Quintero, aux Tamaulipas en Mexique. Parmi les principales caractéristiques de cette espèce, il faut mentionner l'allongement exagéré des pattes, des cerques, des antennes et d'autres extrémités. L'allure de l'espèce la fait resembler beaucoup à Plusiocampa dargilani (Moniez), un Campodeidae cavernicole de France. La structure particulière de la griffe impaire médiane permettra de créer un genre nouveau pour Nicoletia texensis.

\section{REFERENCES}

Nicholas, Brother G. (1962) - Checklist of troglobitic organisms of Middle America. American Mdl. Nat. 68, 165-188.

PACLT, J. (1963) - Thysanura. Fam. Nicoletiidae. Genera Insectorum 216, 1-58.

- (1965) - On the taxonomic criteria for Nicoletiidae (Thysanura) as used in the "Genera Insectorum". Ann. Mag. Nat. Hist., s. 13, 7 (= 1964), 315-319.

REDDELL, J. R. (1965) - A checklist of the cave fauna of Texas. I. The Invertebrata (exclusive of Insecta). Texas J. Sci. 17, 143-187.

- (1966) - A checklist of the cave fauna of Texas. II. Insecta. Texas J. Sci. 18, $25-56$.

UlRICH, C. J. (1902) - A contribution to the subterranean fauna of Texas. Trans. American Micr. Soc. 23, 84-100.

EXPLANATION OF PLATE 127 (1)

Nicoletia texensis from the Quintero caves, natural size (without appendages): $11 \mathrm{~mm}$.

1) Cirolanides texensis Benedict in Ezell's cave; Cirolana bolivari Rioja and Typhlolepidomysis quinterensis Villalobos in the Quintero caves. 


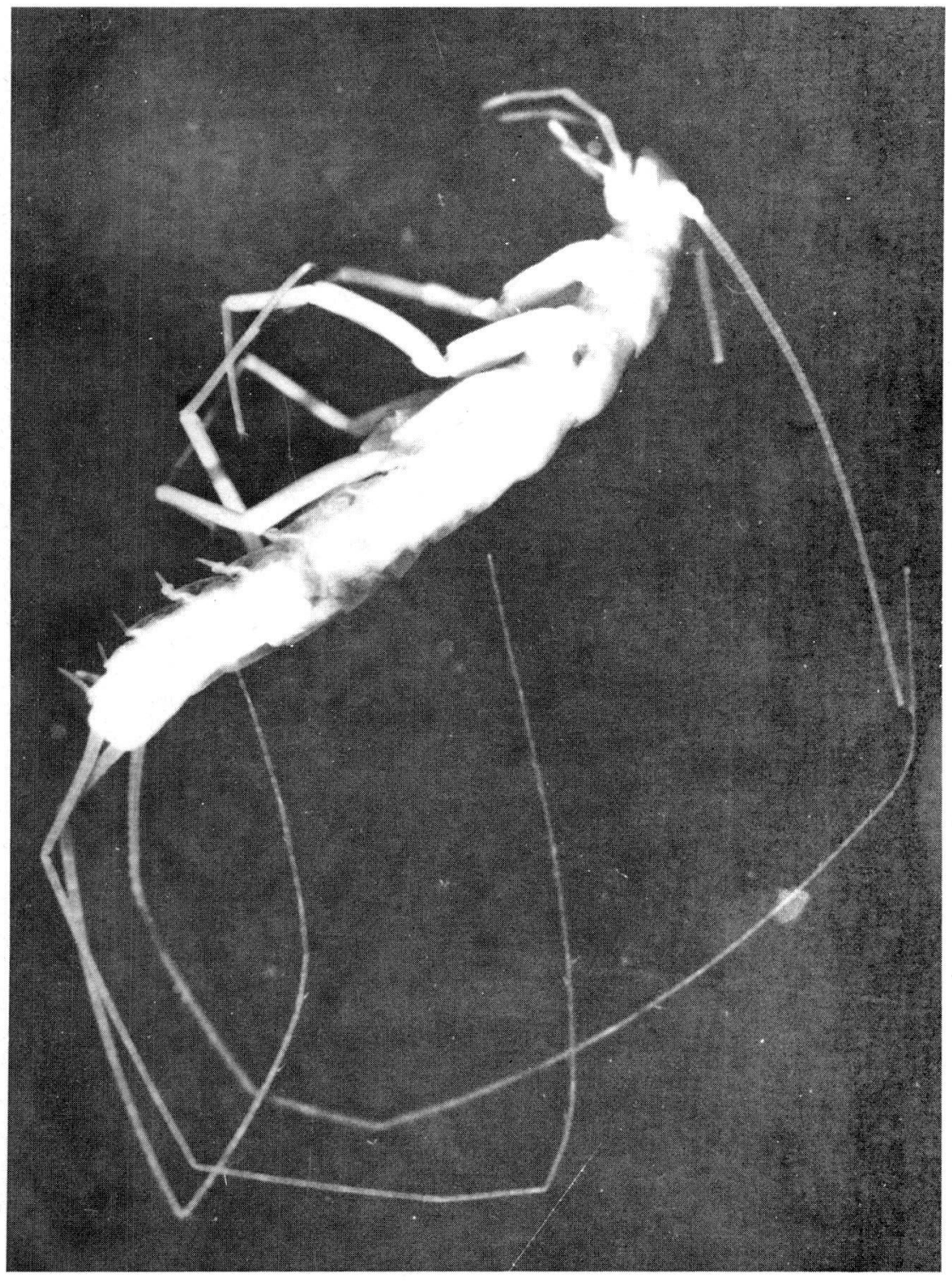

